\title{
Short-Term Toxicity of Mercury and Cadmium to Sparus Aurata Fry, South Mediterranean Sea, Egypt
}

\author{
H. I. Abdel-Shafy ${ }^{\#}$ and Abeer A. El Saharty ${ }^{*}$
}

Water Research and Pollution Control Department, National

Research Center, El-Behous St., Dokki, Cairo and "National

Institute of Oceanography and Fisheries, Al-Anfoshy,

Alexandria, Egypt.

7 HE PRESENT investigation includes extensive monitoring on the physical, chemical and level of $\mathrm{Hg}$ and $\mathrm{Cd}$ as well as in the Sparus aurata fry in El-Mex Bay, Alexandria, Egypt. The study is a bioassay of the lethal concentration of both mercury and cadmium on the Sparus aurata fry. Samples of the fry were collected from El-Mex Bay. The investigation showed that the lethal concentration of mercury and cadmium was $96 \mathrm{hLC}_{50}=0.861 \mathrm{mg} / \mathrm{l}$, and $\mathrm{hLC}_{50}=0.5817 \mathrm{mg} / \mathrm{l}$, respectively. Mortality related to $\mathrm{HgCl}_{2}$ began from $0.4 \mathrm{mg} / \mathrm{l}$ at $96 \mathrm{hr}$. At higher concentrations up to $10 \mathrm{mg} \mathrm{Hg}^{+2} / 1$, mortality occurred within the first $2 \mathrm{hr}$ of exposure. For cadmium nitrate, starting from the concentration of $0.4 \mathrm{mg} \mathrm{Cd}^{+2} / \mathrm{l}$, mortality was recorded at $72 \mathrm{hr}$. Increasing the $\mathrm{Cd}$ concentration to $8.0 \mathrm{mg}$ $\mathrm{Cd}^{+2} / 1$, mortality was observed within the first $4 \mathrm{hr}$ of exposure. Further increase in the exposure time to $96 \mathrm{hr}$, mortality rate reached $100 \%$. The chronic effect study showed that increasing the bioaccumulation rate of metal by the fry bodies is proportional to the increase of metal concentration in the ambient water solution. The obtained results revealed that the Sparus aurata species are more sensitive to mercury than cadmium.

Keywords: Toxicity, Heavy metals, Bio-accumulation, Sparus aurata fry, Bioassay, South Mediterranean Sea .

Metals in surface waters consist of inputs from natural geochemical processes and anthropogenic activities. In addition, heavy metals enter the aquatic environment naturally through weathering of the earth crust ${ }^{(1)}$. These natural geochemical processes are significant non-point sources of metal pollution in surface waters that pose enormous challenges to management and regulatory agencies. Despite the focus on the sources and impacts of metals originating from anthropogenic activities ${ }^{(2,3)}$, recent studies have demonstrated that natural geochemical materials, such as black shales, may be enriched with potentially toxic metals ${ }^{(4-7)}$. In general, studies on heavy metals can be important in two main aspects. First, from the public health point of view, where the attention has been drawn to the necessity of measuring the accumulation of heavy metals;

\#Corresponding author E-mail: hshafywater@yahoo.com 
particularly these metals which pose serious health hazards to humans (e.g. $\mathrm{Cd}$, $\mathrm{Pb}$ and $\mathrm{Hg}$ ). Second, from the aquatic environment view point, the main problem has been to prevent biological deterioration and to identify the sources which threaten ecological equilibrium. Meanwhile, Manmade pollution originated from industrial and municipal wastewater discharged to the surface water without treatment is the major source of heavy metals to the coastal areas ${ }^{(8,9)}$. However, there is scant information on the impacts of natural source of metals on aquatic biota. Thus, a study on the potential effects of these metals will better estimate environmental risk associated with their elevated concentrations in surface waters.

Presently, Alexandria coastal area is subjected to heavy pollution loads from different sources of contamination including industrial and municipal wastewater. Meanwhile, there are some agricultural drainage and industrial wastewater discharged to the east coastal side of the city. Such wastewaters are loaded with organic and inorganic pollutants including nutrients, fertilizers and pesticides residues. The discharged wastewater is sometimes associated with hazardous metals of variable concentrations ranged from very low $(\mu \mathrm{g} / \mathrm{l})$ to much higher concentrations $(\mathrm{mg} / \mathrm{l})$ that are originated from industrial wastes and domestic wastewater ${ }^{(10,11)}$. Heavy metals that are transported to the sea are usually settled on the sediments and accumulated by the living organisms and finally to the food chain ${ }^{(8,12)}$.

It is, generally, agreed that the pollution by inshore waters of the Mediterranean Sea has reached a critical level ${ }^{(13)}$. As a result, aquatic animals are exposed to elevated levels of heavy metals ${ }^{(13)}$. Consequently, the bioaccumulation of heavy metals in aquatic life, especially in fish is of imperative interest owing to the potential detrimental effect on human health. Many investigations revealed that essential and non-essential metals can induce toxic effects in fish by disturbing physiological activities, biochemical processes, reproduction, growth and mortality ${ }^{(14-17)}$. The concern about mercury $(\mathrm{Hg})$, cadmium $(\mathrm{Cd})$ and lead $(\mathrm{Pb})$ pollution in aquatic systems has increased in the last three decades due to high levels of heavy metals observed in fish and the associated risks to human health ${ }^{(16,18)}$.

Mercury is recognized as the most highly toxic metal and must be stringently regulated in the discharged waste ${ }^{(19)}$. The majority of mercury entering the aquatic environment is the inorganic form $\mathrm{Hg}^{+2}$. However, mercury methylation is only one step in a complex cycle that involves a variety of chemical, physical and biological transformations and is considered the highly toxic form of mercury ${ }^{(20)}$. Some authors have already observed that mercury alters calcium homeostasis ${ }^{(21)}$. In addition, mercury is one of the few metal pollutants that had already caused human deaths due to ingestion of contaminated food ${ }^{(21)}$. The aquatic biota is the main mercury source of 
contaminated food chain, since heavy metals undergo bio-magnification in the aquatic lives, presenting their highest concentration in higher tropic level organisms like fish ${ }^{(20)}$.

On the other hand, high concentrations of cadmium and other heavy metals are often associated with badly treated wastewater effluents ${ }^{(8,22)}$. Inorganic cadmium is quite toxic to aquatic organisms. It was reported that cadmium concentrations in all marine organisms, have increased 20 fold during the period from 1987 to 1997 that reached the range of $0.1 \mathrm{mg} / \mathrm{kg}$ wet weight ${ }^{(20)}$. Despite the considerable amount of information available on the effects of individual heavy metals on aquatic organisms, reports on adverse effects of heavy metal mixtures to aquatic organisms and their interactions at lethal and sub lethal levels are quite limited.

Canadian Environmental Quality Guidelines CCME, 1999(23) confirms metals toxicity depends on their form in water. Ions and simple inorganic compounds are more toxic than complicated inorganic and organic metal compounds, e.g. those that are attached to humic substances. Metals are extremely toxic in the early life stages of fish. Mercury and cadmium have a high bioaccumulation capacity. That is why the concentration of these metals in water is a poorer indicator than the respective concentrations in sediments and in fish. Therefore, it is important to study the elevated metal concentrations in Sea waters that cause mortality, growth, and reproductive impairments on Marine biota.

The principal objectives of this study were threefold: (i) to study the physical/chemical characteristics of the Mediterranean Sea water at $25 \mathrm{~km}$ off shore from Alexandria, Egypt. This includes the determination of $\mathrm{Cd}$ and $\mathrm{Hg}$ in the Sea water and in the fry of (Sparus aurata), (ii) to assess the toxic effect of mercury and / or cadmium on the early life stage of a selected fish under the laboratory pilot scale that mimicking the Mediterranean Sea conditions in a bioassay study including determination of the sublethal concentrations of inorganic mercury and cadmium (acute effects), and (iii) to assess the bioaccumulation of mercury and cadmium in the selected fish according to the variable level of these metals in the aquatic media (chronic effect). The selected fish in the present investigation is Sparus aurata fry.

\section{Materials and Methods}

\section{Marine water of the El-Mex bay}

The water quality of the El-Mex Bay; west of Alexandria; South Mediterranean Sea, Egypt was regularly monitored. An extensive biweekly sampling program from the bay water and the fry of Sparus aurata fish was collected for a period of 6 months. The physical and chemical characteristics of the marine water together with the level of $\mathrm{Hg}$ and $\mathrm{Cd}$ in this marine water and in the fry of Sparus aurata fish were determined.

Egypt. J. Chem. 58, No. 5 (2015) 
Bioassay experiment

In this bioassay test, the aquatic organisms are used to detect the effect of heavy metals, namely mercury and cadmium on fry fish.

\section{Acute effect}

This bioassay investigation was carried out according to the recommended criteria concerning the establishment of reliable bioassay application reported by Canadian Environmental Quality Guidelines CCME, $1999^{(23)}$.

a) Test organisms: the used organisms in all designed bioassays in this work were Sparus aurata fry of $2 \mathrm{~cm}$ mean length and $1.5 \mathrm{gm}$ weight. They were collected from El-Mex bay.

b) Test aquaria: Sea water was collected from an area apparently clean and far away from the direct influence of land based discharges. Such off shore Sea waters were collected regularly from the area of $25 \mathrm{~km}$ west of Alexandria for supplying the bioassays requirements. Before using the collected water in the bioassays, it was stored in all glass aquariums in continuous aeration conditions.

c) Holding aquaria: The volume of tested marine water was 20 liters. These 20 liters aquaria were equipped with glass covers of $4 \mathrm{~mm}$ perforation and filters connected with $3 \mathrm{~mm}$ glass tubes. Precautions were also taken in considering the ratio between water and animal weight in the aquarium. This ratio was not exceeding 11 at test solution for each $1 \mathrm{~g}$ of animal weight according to UNEP No.43 (1984). Canadian Environmental Quality Guidelines CCME, $1999^{(23)}$.

d) Experimental test solutions: The heavy metals used in the present experimental study were pure Analytical Reagents (A.R.).

- Inorganic mercury: In the form of A.R. mercuric chloride $\left(\mathrm{HgCl}_{2}\right)$ the concentrations of the experimental test solution in this form ranged from 0.1 to $10 \mathrm{mg} / \mathrm{l}$.

- Inorganic cadmium: In the form of A.R. cadmium nitrate $\mathrm{Cd}\left(\mathrm{NO}_{3}\right)_{2}$, the tested concentrations ranged from $0.1 \mathrm{mg} / \mathrm{l}$ to $10 \mathrm{mg} / \mathrm{l}$.

- Control bioassay: in a controlled similar aquarium an identical experimental work was conducted for each investigation during the whole period without adding any metals. The obtained results are used as the controlled reference and were correlated with the experimental ones.

\section{Chronic effects}

Accumulation of inorganic mercury and cadmium

The bioassay experiments were carried out by exposing the fish fry to mercury and / or cadmium for periods longer than 4 days (4, 8, 14 and 21 days). The purpose is to study the bioaccumulation rate by the fry survival in accordance with chronic exposure. In these experiments, the fry were fed regularly every four days.

Egypt. J. Chem. 58, No. 5 (2015) 
During these relatively short-term experiments, the Sparus aurata fry were held in controlled ambient conditions (temperature $=16{ }^{\circ} \mathrm{C}, \mathrm{pH}=7.8$ and salinity $35.5 \%$ ) for two weeks. At the beginning of the experiment, 120 fry were introduced into three vessels (40 fry individuals in each) with different concentrations in triplicate assays. These concentrations covered the range between 0.1 to $0.4 \mathrm{mg} / 1 \mathrm{Hg}$ as mercuric chloride and from 0.5 to $4.0 \mathrm{mg} \mathrm{Cd}{ }^{+2} / 1$ as cadmium nitrate.

The test organisms in all these bioassays were, again, Sparus aurata fry of $2 \mathrm{~cm}$ mean length and $1.5 \mathrm{gm}$ weight. They were collected from the same location (i.e. $25 \mathrm{~km}$ offshore South Mediterranean Sea, El-Mex bay, west of Alexandria, Egypt).

During the experiments, the feeding materials were analyzed to determine the content of mercury and cadmium. The analyses showed that concentrations were below the detection limit. For $\mathrm{Hg}$ and $\mathrm{Cd}$, the detection limit was $0.01 \mu \mathrm{g} / \mathrm{l}$ and $0.03 \mu \mathrm{g} / \mathrm{l}$, respectively. On the other hand, daily water samples from the experimental aquarium were taken for the determination of mercury and cadmium concentration. Meanwhile, seven individuals of test-fry fish were removed from each test solutions at 4, 8, 14 and 21 days for the same purpose.

\section{Determination of mercury and cadmium contents in fish samples \\ Inorganic mercury and cadmium in fish}

The Sea water samples were filtered through Whitman filters paper No. 4 then acidified by $\mathrm{HNO}_{3}$ to below $\mathrm{pH}$ 2.0. In this method $1 \mathrm{gm}$ fresh whole fry were digested according to the procedure described by $\mathrm{APHA}^{(24)}$ using concentrated $\mathrm{HNO}_{3}$ followed by $\mathrm{H}_{2} \mathrm{O}_{2}$. Mercury concentrations in water and fish samples were measured using cold vapor (Reducing Vaporization Mercury Analyzer) techniques of the Atomic Absorption spectrophotometer-AAS (Varian Tectron 1250). Meanwhile, cadmium concentrations in water and fish samples were detected using the flameless techniques of the same AAS (Varian Tectron 1250). Level of metals in fresh fish that were not exposed to contaminated water was also determined with the same procedures and the results were employed as control.

\section{Results and Discussion}

Physical and chemical characteristics of El-Mex Bay

Results (Table 1) indicate that there is no great seasonal variation in the physical and chemical characteristics of the studied marine water of El-Max Bay. The low level of both nitrates and phosphates indicates that there is no sewage or agriculture drainage was discharged to this site. However, the level of $\mathrm{Hg}$ and $\mathrm{Cd}$ were relatively low in both marine water and the Sparus aurata fry (Table 1). 
TABLE 1. Physical and chemical characteristics as well as the level of mercury and cadmium in water and the fry of Sparus aurata fry collected from the ElMax Bay (number of analyzed samples=12).

\begin{tabular}{|c|c|c|c|c|}
\hline Parameters & No. of $S$. & Min. & Max. & Mean values \\
\hline Temperature & 12 & $10^{\circ} \mathrm{C}$ & $19^{0} \mathrm{C}$ & $16^{\circ} \mathrm{C}$ \\
\hline $\mathrm{pH}$ & 12 & 7.8 & 8.9 & 8.7 \\
\hline $\mathrm{S} \%_{0}$ & 12 & 38.80 & 38.98 & 38.9 \\
\hline Dissolved Oxygen & 12 & $4 \mathrm{mg} \mathrm{O}_{2} / 1$ & $6 \mathrm{mg} \mathrm{O}_{2} / \mathrm{l}$ & $5 \mathrm{mg} \mathrm{O}_{2} / \mathrm{l}$ \\
\hline $\begin{array}{l}\text { Total Phosphates (as Phosphorus) } \\
(\mu \mathrm{g} \text { P/l) }\end{array}$ & 12 & $1.491 \mu \mathrm{g} / 1$ & $1.697 \mu \mathrm{g} / \mathrm{l}$ & $1.566 \mu \mathrm{g} / 1$ \\
\hline Total Nitrates (as Nitrogen) ( $\mu \mathrm{g} N / \mathrm{l})$ & 12 & $0.06 \mu \mathrm{g} / 1$ & $0.10 \mu \mathrm{g} / 1$ & $0.08 \mu \mathrm{g} / \mathrm{l}$ \\
\hline Organic matter & 12 & $2.80 \mathrm{mg} / \mathrm{l}$ & $3.19 \mathrm{mg} / \mathrm{l}$ & $3.0 \mathrm{mg} / \mathrm{l} \mathrm{O}_{2} / \mathrm{l}$ \\
\hline Background dissolved $\mathrm{Hg}$ & 12 & $0.02 \mu \mathrm{g} / 1$ & $0.02 \mu \mathrm{g} / \mathrm{l}$ & $0.02 \mu \mathrm{g} / \mathrm{l}$ \\
\hline Background dissolved $\mathrm{Cd}$ & 12 & $0.06 \mu \mathrm{g} / \mathrm{l}$ & $0.06 \mu \mathrm{g} / \mathrm{l}$ & $0.06 \mu \mathrm{g} / \mathrm{l}$ \\
\hline $\begin{array}{l}\text { Fry Sparus aurata fish } \mathrm{Hg}(\mathrm{mg} / \mathrm{kg} \\
\text { dry weight) }\end{array}$ & 12 & 0.001 & 0.002 & 0.002 \\
\hline $\begin{array}{l}\text { Fry Sparus aurata fish Cd (mg/kg } \\
\text { dry weight) }\end{array}$ & 12 & 0.003 & 0.003 & 0.003 \\
\hline
\end{tabular}

No. of $\mathrm{S}=$ number of samples, $\quad$ Min. = Minimum, $\quad$ Max. = maximum, $\mathrm{S} \% 0=$ Salinity

Lethal concentrations of inorganic mercury (acute effects)

When the Sparus aurata fry were exposed to $0.1,0.2$ and $0.3 \mathrm{mg} / \mathrm{Hg}^{+2}$ in the chloride form no mortality occurred within $96 \mathrm{hr}$ period. However, mortality was associated by increasing the level of $\mathrm{Hg}^{+2}$ to higher than $0.2 \mathrm{mg} / \mathrm{l} \mathrm{Hg}^{+2}$. The results showed that as $\mathrm{Hg}$ concentration increases, mortality rate increases (Table 2). At concentrations of $0.4,0.5,0.6,0.7$ and $0.8 \mathrm{mg} / 1 \mathrm{Hg}^{+2}$, the mortality rate was $15,35,65,85$ and $85 \%$, respectively. When the concentration reached $1.0 \mathrm{mg} / \mathrm{l} \mathrm{Hg}^{+2}, 100 \%$ mortality was recorded within $96 \mathrm{hr}$. By increasing the concentration up to $5 \mathrm{mg} / \mathrm{l} \mathrm{Hg}^{+2}$ and after $36 \mathrm{hr}$ exposure, the organisms exhibited lazy movement and tend to lie on the bottom of test vessels. In these experiments $100 \%$ mortalities were recorded at $48 \mathrm{hr}$ exposure time. Most mortalities related to $\mathrm{HgCl}_{2}$ occurred at high concentrations (namely $10 \mathrm{mg} / \mathrm{l}$ $\mathrm{Hg}^{+2}$ ) within the first $2 \mathrm{hr}$ of exposure time. It is worth mentioning that during the first $20 \mathrm{~min}$ of exposures and at concentration of $10 \mathrm{mg} / \mathrm{H} \mathrm{Hg}^{+2}$, the swimming activity of the fish increased, particularly towards the water surface. Within 1 to $1 \frac{1 / 2}{h r}$ prior to death, test organisms began to increase their respiratory movements and they tend to go towards the water surface before death. On the other hand, no mortality was observed among the control groups during the whole period of this assay.

The acute toxicity assays for the fry fish indicated that $\mathrm{LC}_{50}$ values for $96 \mathrm{hr}$ exposure $\left(96 \mathrm{~h}-\mathrm{LC}_{50}\right.$ ) was 0.861 as mercuric chloride (Fig. 1).

Baldwin, et al. ${ }^{(25)}$, reported that $1 \mathrm{mg} / \mathrm{l}$ of mercuric chloride killed $90 \%$ of adult bamacles Balanas balanoides within $48 \mathrm{hr}$. However, they also reported

Egypt. J. Chem. 58, No. 5 (2015) 
that the metamorphoses of eyprides are affected only with about $16.6 \mathrm{mg} / \mathrm{l}$ of mercuric chloride. Our present study recorded that within $48 \mathrm{hr}$ and at $1.0 \mathrm{mg} / \mathrm{l}$ of mercuric chloride $85 \%$ mortality of Sparus aurata fry was observed, however, by increasing the concentration to $10.0 \mathrm{mg} / \mathrm{l}$, the mortality reached $100 \%$ within the first $2 \mathrm{hr}$ (Table 2).

TABLE 2. Mortality percentage of Sparus aurta fry at different time and concentration of $\mathrm{HgCl}_{2}$.

\begin{tabular}{|l|c|c|c|c|c|c|c|c|c|c|c|c|c|}
\hline Concentration & $\mathbf{0}$ & $\mathbf{0 . 1}$ & $\mathbf{0 . 2}$ & $\mathbf{0 . 3}$ & $\mathbf{0 . 4}$ & $\mathbf{0 . 5}$ & $\mathbf{0 . 6}$ & $\mathbf{0 . 7}$ & $\mathbf{0 . 8}$ & $\mathbf{1}$ & $\mathbf{2}$ & $\mathbf{5}$ & $\mathbf{1 0}$ \\
\hline Time (hours) & & \multicolumn{10}{|c|}{ Mortality Percentage } \\
\hline 1 & 0 & 0 & 0 & 0 & 0 & 0 & 0 & 0 & 0 & 0 & 0 & 0 & 0 \\
\hline 2 & 0 & 0 & 0 & 0 & 0 & 0 & 0 & 0 & 0 & 0 & 0 & 0 & 100 \\
\hline 4 & 0 & 0 & 0 & 0 & 0 & 0 & 0 & 0 & 0 & 0 & 0 & 15 & 100 \\
\hline 8 & 0 & 0 & 0 & 0 & 0 & 0 & 0 & 0 & 0 & 15 & 15 & 35 & 100 \\
\hline 16 & 0 & 0 & 0 & 0 & 0 & 0 & 0 & 0 & 15 & 35 & 35 & 50 & 100 \\
\hline 24 & 0 & 0 & 0 & 0 & 0 & 0 & 0 & 15 & 35 & 50 & 60 & 65 & 100 \\
\hline 36 & 0 & 0 & 0 & 0 & 0 & 0 & 15 & 35 & 50 & 65 & 65 & 85 & 100 \\
\hline 48 & 0 & 0 & 0 & 0 & 0 & 0 & 35 & 50 & 65 & 85 & 85 & 100 & 100 \\
\hline 72 & 0 & 0 & 0 & 0 & 0 & 15 & 50 & 65 & 85 & 100 & 100 & 100 & 100 \\
\hline 96 & 0 & 0 & 0 & 0 & 15 & 35 & 65 & 85 & 85 & 100 & 100 & 100 & 100 \\
\hline
\end{tabular}

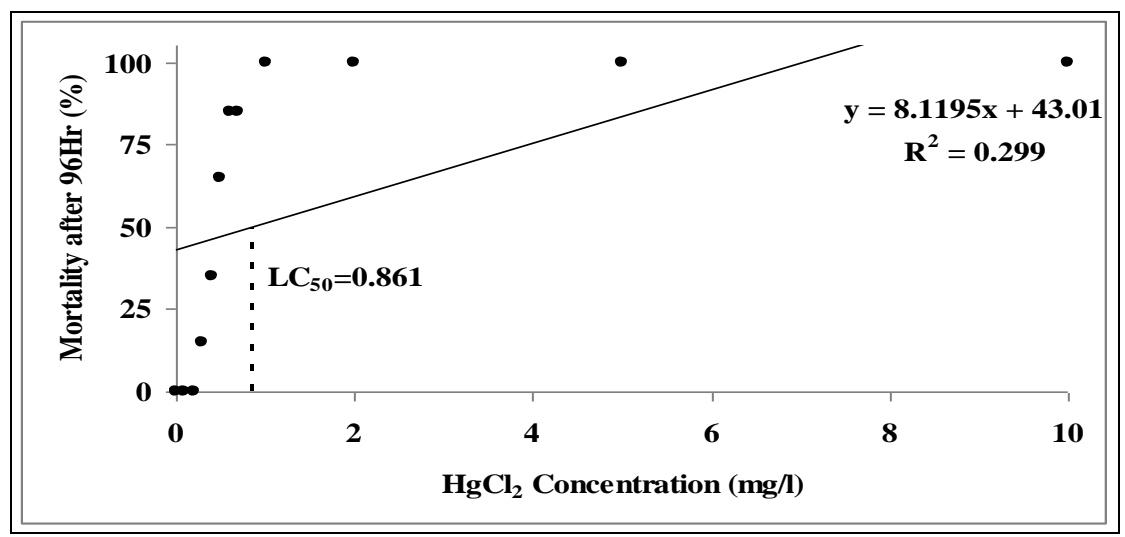

Fig. 1. 96-1C 5 calibration curve of mercury chloride for Sparus aurta fry.

Regression analysis test for lethality of mercuric chloride

As shown in Fig. 1 the percentage of mortality and the concentrations of mercuric chloride are highly correlated. The correlation coefficient $\left(\mathrm{R}^{2}=0.299\right)$ and the regression equation is represented as follows:

$$
\mathrm{Y}=8.1195 \mathrm{X}+43.01
$$

where $\mathrm{X}$ and $\mathrm{Y}$ are $\mathrm{Hg}$ concentration as $\mathrm{mg} / \mathrm{l}\left(\mathrm{HgCl}_{2}\right)$ and percentage of observed mortality in test fry after $96 \mathrm{hr}$ exposure, respectively. 
Lethal concentration of inorganic cadmium (short-term bioassay)

Results (Table 3) illustrated that "no" mortality was observed at concentrations between 0.1 and $0.2 \mathrm{mg} / \mathrm{Cd}^{+2}$ as cadmium nitrate, within the examined exposure time. Starting from the concentration of $0.4 \mathrm{mg} \mathrm{Cd}^{+2} / 1$, mortality was recorded at $72 \mathrm{hr}$. Increasing $\mathrm{Cd}$ concentration to $8.0 \mathrm{mg} \mathrm{Cd}^{+2} / 1$, mortality was observed within the first $4 \mathrm{hr}$ of exposure time. It was noted that, the test organisms persisted for a short time, however within $45 \mathrm{~min}$, the fry began to swim actively, and finally their behavior returned back to normal. Further increase in the exposure time to $96 \mathrm{hr}$, mortality rate reached $100 \%$ (Table 3).

The results of acute cadmium toxicity bioassay are illustrated in Fig. 2. This study indicates that the $96 \mathrm{~h}-\mathrm{LC}_{50}$ value for cadmium on Sparus aurata fry is 2.315 as cadmium nitrate (Fig. 2).

These results proved that Sparus aurata species are more sensitive to mercury than cadmium. It has been reported by Van Sprang \& Janssen ${ }^{(3)}$ that the uptake and toxicity of metals depend on their bioavailability and is influenced by the water quality variables including salinity and temperature.

TABLE 3. Mortality percentage of Sparus aurta fry at different times and concentrations of cadmium nitrate .

\begin{tabular}{|c|l|l|l|l|l|l|l|l|l|l|}
\hline Concentration & $\mathbf{0}$ & $\mathbf{0 . 1}$ & $\mathbf{0 . 2}$ & $\mathbf{0 . 4}$ & $\mathbf{0 . 6}$ & $\mathbf{0 . 8}$ & $\mathbf{2}$ & $\mathbf{4}$ & $\mathbf{8}$ & $\mathbf{1 0}$ \\
\hline Time (hours) & \multicolumn{10}{|c|}{ Mortality Percentage } \\
\hline 1 & 0 & 0 & 0 & 0 & 0 & 0 & 0 & 0 & 0 & 0 \\
\hline 2 & 0 & 0 & 0 & 0 & 0 & 0 & 0 & 0 & 0 & 100 \\
\hline 4 & 0 & 0 & 0 & 0 & 0 & 0 & 0 & 0 & 20 & 100 \\
\hline 8 & 0 & 0 & 0 & 0 & 0 & 0 & 0 & 20 & 40 & 100 \\
\hline 16 & 0 & 0 & 0 & 0 & 0 & 0 & 20 & 40 & 50 & 100 \\
\hline 24 & 0 & 0 & 0 & 0 & 0 & 20 & 40 & 55 & 65 & 100 \\
\hline 36 & 0 & 0 & 0 & 0 & 20 & 40 & 55 & 60 & 70 & 100 \\
\hline 48 & 0 & 0 & 0 & 0 & 40 & 55 & 60 & 65 & 75 & 100 \\
\hline 72 & 0 & 0 & 0 & 20 & 55 & 60 & 65 & 70 & 80 & 100 \\
\hline 96 & 0 & 0 & 0 & 40 & 65 & 70 & 75 & 75 & 100 & 100 \\
\hline
\end{tabular}

Regression analysis test of lethality of cadmium nitrate

Figure 2 represents the regression line. The results reveal that the percentage of mortality and the concentration of cadmium nitrate are highly correlated. The correlation coefficient $\left(\mathrm{R}^{2}=0.5817\right)$ and the regression equation is:

$$
\mathrm{Y}=8.4615 \mathrm{X}+30.415
$$

where $\mathrm{X} \& \mathrm{Y}$ are cadmium concentration as $\mathrm{Cd}\left(\mathrm{NO}_{3}\right)_{2} \mathrm{mg} / \mathrm{l}$ and percentage of mortality in test fry after $96 \mathrm{hr}$ exposure, respectively. 


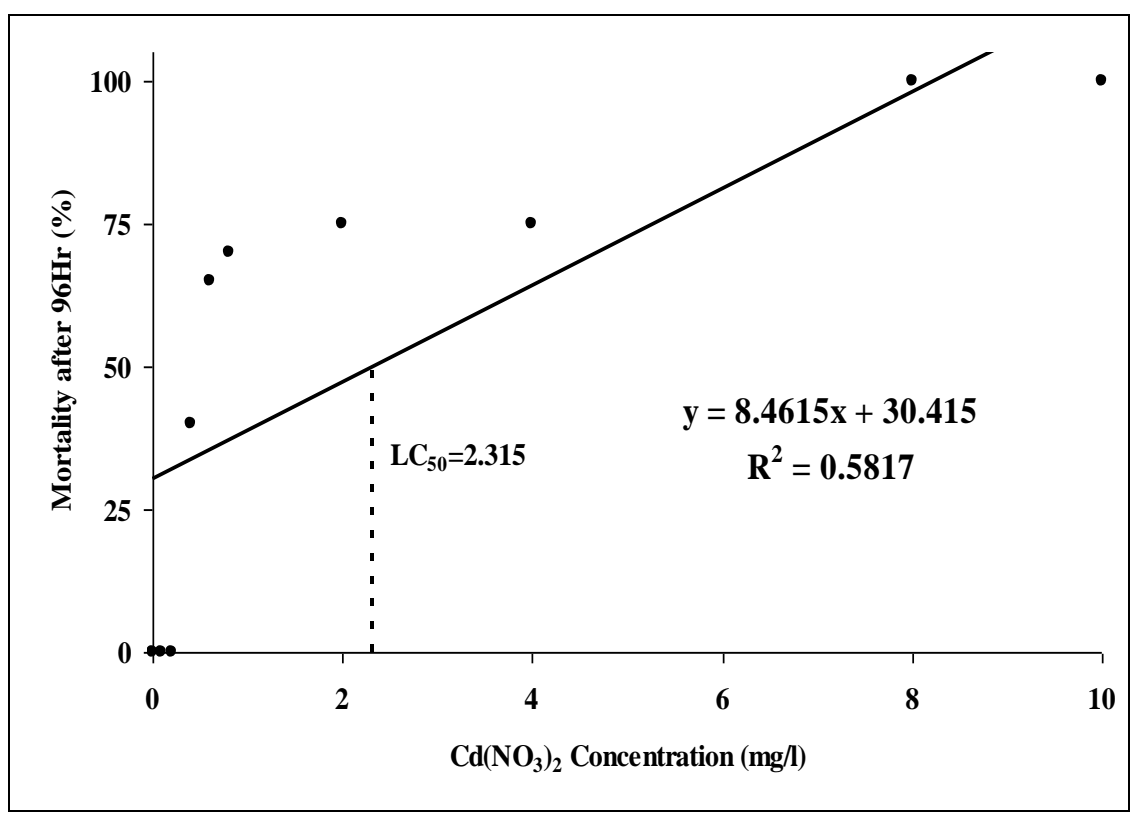

Fig. 2. 96-LC50 calibration curve of cadmium nitrate for Sparus aurta fry .

Sublethal concentrations of inorganic mercury and cadmium (chronic effects)

The obtained results are given in Tables 4 and 5. In general, this bioassay proved that mercuric chloride and cadmium nitrate are concentrated by fry in appreciable amounts from the surrounding water (Fig. 3 and 4).

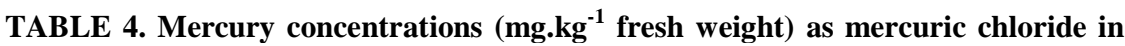
the fry of Sparus aurata fry (chronic effect or sublethal effect).

\begin{tabular}{|l|c|c|c|c|c|c|c|c|c|c|c|c|}
\hline $\begin{array}{c}\text { Concentration } \\
\text { mg. } .^{-1}\end{array}$ & \multicolumn{3}{|c|}{ 4 days } & \multicolumn{3}{c|}{8 days } & \multicolumn{3}{c|}{14 days } & \multicolumn{3}{c|}{21 days } \\
\hline & Mean & SD & p $<$ & Mean & SD & P< & Mean & SD & P< & Mean & SD & P< \\
\hline Control & 0.002 & 0 & & 0.002 & 0 & & 0.002 & 0 & & 0.004 & 0 & \\
\hline 0.1 & 0.024 & 0.001 & 0.001 & 0.039 & 0.0005 & 0.001 & 0.045 & 0.0030 & 0.001 & 0.048 & 0.001 & 0.001 \\
\hline 0.2 & 0.0 .43 & 0.0015 & 0.001 & 0.070 & 0.0008 & 0.001 & 0.075 & 0.0005 & 0.001 & 0.081 & 0.001 & 0.001 \\
\hline 0.3 & 0.067 & 0.028 & 0.050 & 0.115 & 0.0011 & 0.001 & 0.120 & 0.0100 & 0.001 & 0.123 & 0.001 & 0.001 \\
\hline 0.4 & 0.086 & 0.005 & 0.001 & 0.130 & 0.0050 & 0.001 & 0.135 & 0.0008 & 0.001 & 0.139 & 0.001 & 0.001 \\
\hline
\end{tabular}




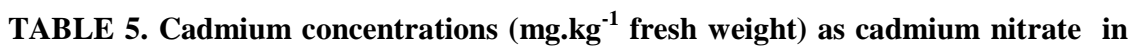
the fry of Sparus aurata (chronic effect or sublethal effect).

\begin{tabular}{|l|c|c|c|c|c|c|c|c|c|c|c|c|}
\hline Concentration & \multicolumn{3}{|c|}{ 4 days } & \multicolumn{3}{c|}{ 8 days } & \multicolumn{3}{c|}{ 14 days } & \multicolumn{3}{c|}{ 21 days } \\
\hline (mg..$\left.^{-1}\right)$ & Mean & SD & P & Mean & SD & p $<$ & Mean & SD & P & Mean & SD & P \\
\hline Control & 0.005 & 0 & & 0.006 & 0 & & 0.006 & 0 & & 0.006 & 0 & \\
\hline 0.5 & 0.096 & 0.001 & 0.003 & 0.19 & 0.005 & 0.013 & 0.42 & 0.002 & 0.004 & 0.49 & 0.001 & 0.003 \\
\hline 1 & 0.171 & 0.005 & 0.013 & 0.3 & 0.009 & 0.022 & 0.62 & 0.001 & 0.003 & 0.72 & 0.576 & 1.431 \\
\hline 2 & 0.252 & 0.003 & 0.006 & 0.43 & 0.002 & 0.005 & 0.8 & 0.002 & 0.004 & 0.97 & 0.001 & 0.002 \\
\hline 4 & 0.351 & 0.006 & 0.015 & 0.56 & 0.001 & 0.001 & 0.97 & 0.002 & 0.005 & 1.21 & 0.005 & 0.012 \\
\hline
\end{tabular}

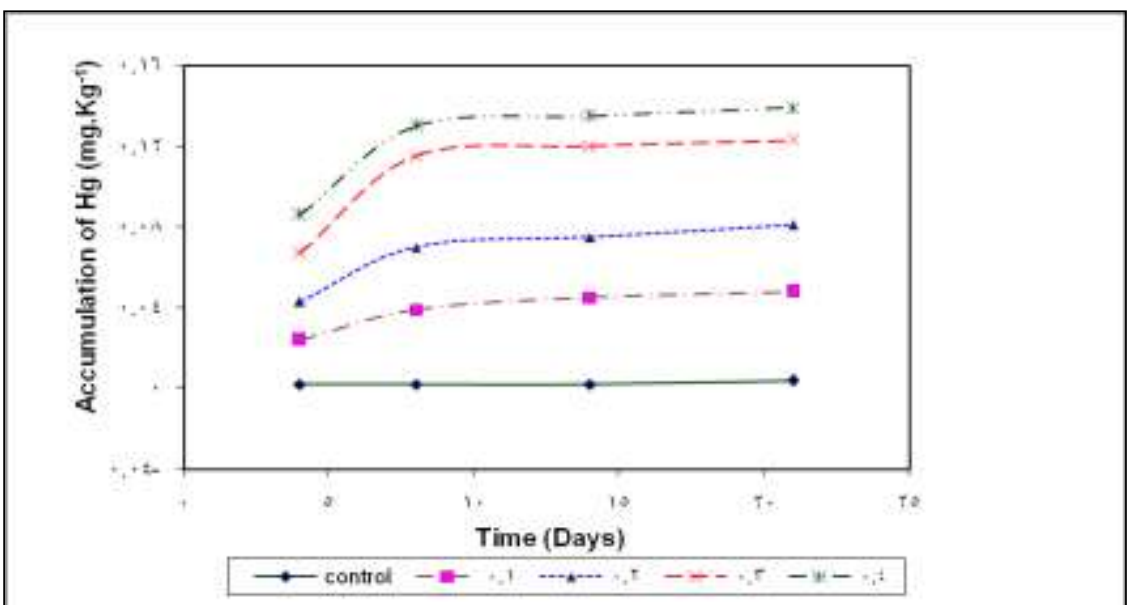

Fig. 3. The bioaccumulation rate of mercury by fish at different exposure time and variable metal concentration.

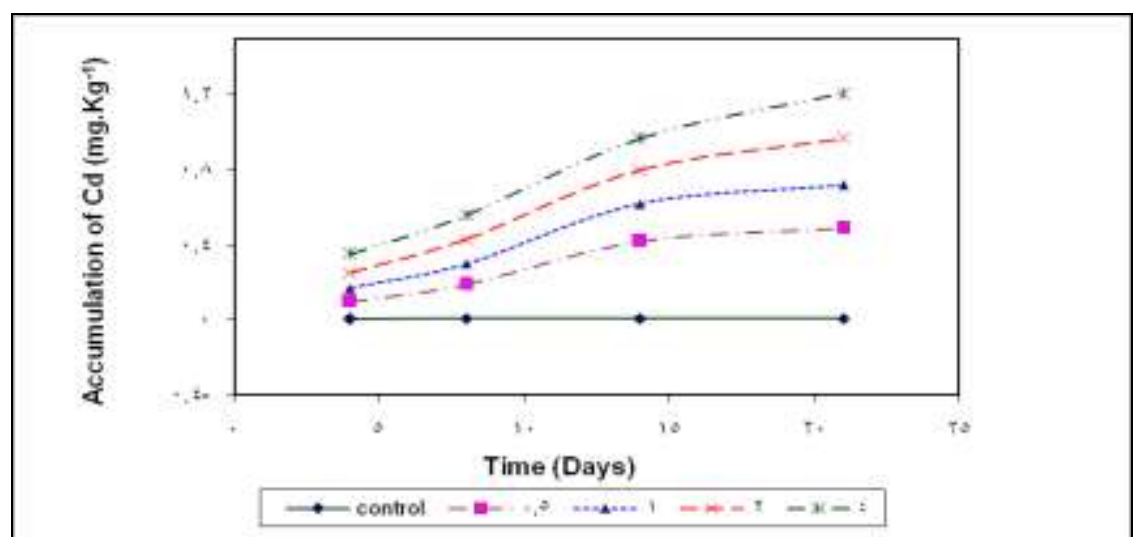

Fig. 4. The bioaccumulation rate of cadmium by fish at different exposure time and variable metal concentration.

Egypt. J. Chem. 58, No. 5 (2015) 


\section{For mercury}

Results (Table 4) indicated that increasing time of exposure increases accumulation of $\mathrm{Hg}$ in the Sparus aurata fry as chronic effect. However, the optimum increase was recorded after 8 days exposure time. At concentration of $0.4 \mathrm{mg} / \mathrm{l} \mathrm{Hg}^{+2}$ and after exposure time for 4 days, the concentration in the fry reached $0.086 \mathrm{mg} / \mathrm{kg}$ fresh weight. By increasing the time of exposure to 8 days, further increase in metal bioaccumulation by the fry was recorded after which almost stationary state was exhibited. The maximum $\mathrm{Hg}$ accumulations were detected after 21 days at which the level of $\mathrm{Hg}$ reached $0.048,0.081,0.123$ and $0.139 \mathrm{mg} / \mathrm{kg}$ (fresh weight) at the variable ambient solution conditions namely $0.1,0.2,0.3$ and $0.4 \mathrm{mg} / 1$, respectively (Table 4 ). Reaching the stationary state may be explained by the relative saturation of the fry at the corresponding time of exposure and ambient concentration. The highest increase in the accumulation was exhibited at 4 days and 8 days after which a steady slight increase at 14 and 21 days took place.

\section{For cadmium}

Results (Table 5) obtained exhibited that the same trend related to $\mathrm{Hg}$ accumulation by the fry, i.e. a steady increase in the accumulation of $\mathrm{Cd}$ by the Sparus aurata fry was recorded as the exposure time increases from 4 to 21 days. The $\mathrm{Cd}$ accumulation by the fry after 4 days exposure time was 0.096 , $0.171,0.252$ and $0.351 \mathrm{mg} / \mathrm{kg}$ (fresh weight) at the variable ambient solution conditions namely $0.5,1.0,2.0$ and $4.0 \mathrm{mg} / \mathrm{l}$, respectively (Table 5). Increasing the time of exposure to 21 days at the same ambient conditions, $\mathrm{Cd}$ accumulation increased to $0.49,0.72,0.97$ and $1.21 \mathrm{mg} / \mathrm{kg}$ (fresh weight) at the same variable ambient solution conditions namely $0.5,1.0,2.0$ and $4.0 \mathrm{mg} / \mathrm{l}$, respectively (Table 5).

In the present assay, accumulation of mercury by fry showed that the maximum burden quantity of mercury reached $0.139 \mathrm{mg} / \mathrm{kg}$ (fresh weight) in the examined species as it was subjected to mercury contamination condition in their surrounding waters of $0.40 \mathrm{mg} / \mathrm{l}$ for a period of 21 days at least. It was stated by Protasowicki ${ }^{(26)}$ and confirmed by Benson et al. ${ }^{(27)}$ that the accumulation rate of mercury depends upon the biological as well as physiological state of the tested fry.

According to Larsson et al. ${ }^{(14)}$ and Protasowicki ${ }^{(26)}$ the gills are the primary route for mercury accumulation inside the fish body and that the mercury passes through the epithelium of the gills then to the blood by passive diffusion. It was further reported by Protasowicki ${ }^{(26)}$ that mercury inters the blood may be bind to plasma proteins or become associated with lipids and transported through the body. Both inorganic and organic mercuric salts were reported to be more soluble in lipid than in aqueous solution ${ }^{(26)}$. The distribution of mercury amongst tissues is probably due to number of factors, including the degree of vascularization of tissue, the chemical nature of the tissue, and the chemical form of mercury. In mammals, tissues such as kidneys that are heavily vascularized and 
characterized by large internal surface area accumulate larger amounts of mercury ${ }^{(28)}$.

Several mechanisms have been proposed ${ }^{(29,28)}$ for uptake of trace elements by marine organisms that can be summarized as follows:

1) Adsorption of ions at membrane-water interface.

2) Adsorption by active and or passive diffusion of metal ions from sea water across semi-preamble membranes into the body fluids.

3) Ingestion of ions with food or in combination with particulate matter and absorption through the gut-wall.

In our case, the first and second mechanisms are possible, and to lesser extend the third mechanism since fry Sparus aurata have been fed every 4 days with food of almost free metals content.

Helcom ${ }^{(30)}$ found that $\mathrm{Hg}^{+2}$ concentrations in some marine fish species reached 0.0250 to $0.155 \mathrm{mg} / \mathrm{kg}$. Meanwhile Zarski et al. ${ }^{(31)}$ detected nearly the same range in fish collected from non-contaminated areas.

In fish from environments with elevated mercury concentration, the range runs up to $9.8 \mathrm{mg} / \mathrm{kg}^{(32)}$ which is the highest mercury concentration yet reported in fish. Such result reflects the rate of mercury accumulation by fish in proportional to metal concentration in the surrounding waters. This founding is in good agreement with the present investigation where the accumulation rate depends proportionally on concentration of metal in the surrounding waters.

Low tolerance of mercury compounds by mollusks especially organicmercuric compounds was reported by Hofer \& Lakner ${ }^{(33)}$. They confirmed that mercury at low concentration as $0.1 \mathrm{mg} / \mathrm{l}$ in short-term experiments had toxic effects at which the $\mathrm{Hg}$ accumulation reached $0.1 \mathrm{mg} / \mathrm{kg}$ fresh weight. This value is corresponding to the results obtained in the present bioassay in terms of exposing the Sparus aurata fry to mercury concentration of $0.3 \mathrm{mg} / \mathrm{l}$ for a period of 8 days (Table 4). Higher accumulation was obtained at both longer exposure time and higher metal concentration values (Fig. 3).

In the present work, it appears that accumulation of cadmium in the fry of Sparus aurata followed a remarkable trend. When an ambient concentration of Cd increased, the rate of accumulation increased (Table 5). This may be due to the capability of the physiological systems of the fish to carry on extra burden of such toxic metal. This was confirmed by other authors ${ }^{(17,27)}$. Nevertheless, it is clear that accumulation of cadmium in the whole fish body increased with increasing the concentration of this metal in the media. In addition, the longer exposure time the relatively higher accumulation of $\mathrm{Cd}$ was recorded. $\mathrm{Cd}\left(\mathrm{NO}_{3}\right)_{2}$ was augmented from $0.351 \mathrm{mg} / \mathrm{kg}$ to $1.21 \mathrm{mg} / \mathrm{kg}$ when the exposure were extended from 4 to 21 days at concentration of $4.0 \mathrm{mg} \mathrm{Cd} / 1$. Wiener ${ }^{(34)}$ reported 
that the exposure of common guppy Lebistes reticulates to sublethal concentration of zinc sulphate and lead nitrate for a period of 3 months, the accumulated amounts were $1.15 \mathrm{mg} / \mathrm{kg}$ and $1.25 \mathrm{mg} / \mathrm{kg}$, respectively.

The overall results of the present investigation reveal the following:

1. The west coast of Alexandria; namely; El-Mex Bay is free of wastewater discharge. The concentration of $\mathrm{Hg}$ and $\mathrm{Cd}$ in the marine water and in the fish tissue collected from this Bay is within the low level

2. Mortality rate of the Sparus aurata fry reached $100 \%$ after $96 \mathrm{hr}$ exposure at the concentration of $1.0 \mathrm{mg} / \mathrm{l}$ for $\mathrm{Hg}$ and $8.0 \mathrm{mg} / \mathrm{l}$ for $\mathrm{Cd}$.

3. Both mercury and cadmium have a high bioaccumulation capacity by fish.

4. Short-term exposing the Sparus aurata fry to $0.4 \mathrm{mg} \mathrm{Hg} / \mathrm{l}$ and $4.0 \mathrm{mg}$ $\mathrm{Cd} / \mathrm{l}$ up to 21 days resulted in accumulating $0.139 \mathrm{mg} \mathrm{Hg} / \mathrm{kg}$ and $1.21 \mathrm{mg}$ $\mathrm{Cd} / \mathrm{kg}$ fresh weight, respectively.

5. The chronic effect study indicated that increasing the accumulation rate of $\mathrm{Hg}$ inside the fry bodies is proportional to the increase of $\mathrm{Hg}$ concentration in the aquatic media up to certain extent. After which the accumulation rate of metal by the fry did not increase with any corresponding increase of metal in the aquatic media. When the ambient concentration of $\mathrm{Cd}$ was doubled, the rate of accumulation was slightly increased due to the saturation of the physiological systems in the fish. This rate of accumulation is known to follow the first order kinetic reaction.

\section{Conclusion and Recommendation}

The bio-available fraction of metal is corresponding to high mortality rate of the Sparus aurata fry. It is, therefore, strongly recommended to protect the marine environment from any discharge of wastewater particularly that contaminated with heavy metals or other hazard pollutants. Fishing in such closed areas should be absolutely banned due to the tendency of metals accumulation by fish.

Acknowledgements: The authors wish to express their deep appreciation to the facilities provided by the project titled "Sustainable Development for Wastewater Treatment and Reuse via Constructed Wetlands in Sinai (SWWTR)" that funded STDF of Egypt.

\section{References}

1. Forstner, U. and Wittmann, G.T.W., Metal Pollution in the Aquatic Environment. Springer-Verlag, Berlin, pp. 30-61 (1983).

2. Bailey, H.C., Hrassol, R., Elphick, R.R., Mulhall, A., Hunt, P., Tedmanson, L. and Lovell, A., Application of Ceriodaphnia dubia for whole effluent toxicity tests in the Hawkesbury-Neupean watershed, New South Wales, Australia: Method development and validation. Environmental Toxicology and Chemistry, 19, 88-93 (2000). 
3. Van Sprang, P.A. and Janssen, C.R., Toxicity identification of trace metals: development of toxicity identification fingerprints. Environmental Toxicology and Chemistry, 20, 2604-2610 (2001).

4. Coveney, R.M. Jr. and Glasock, M.D., A review of the origins of metal-rich Pennsylvanian black shales, central USA, with an inferred role for basin brines. Applied Geochemistry, 4, 347-367 (1989)

5. Lee, J., Chon, H., Kim, J., Kim, K. and Moon, H., Enrichment of potentially toxic elements in areas underlain by black shales and slates in Korea. Environmental Geochemistry and Health, 20,135-147 (1998).

6. Petsch, S.T., Berner, R.A. and Eglington, T.I., A field study of the chemical weathering of ancient sedimentary organic matter. Organic Geochemistry, 31, 475487 (2000).

7. Ogendi, G.M., Hannigan, R.E., Farris, J.L. and Smith, D. The impact of black shale weathering on sediment quality. Journal Arkansas Academy of Science, 58, 8490 (2004b).

8. Abdel-Shafy, H.I. and Aly, R.O., Wastewater Management in Egypt. In: Wastewater Reuse-Risk Assessment, Dicision-Making and Environmental Security . Mohammed K. Zaidi (Ed.) Springer Publisher, Netherland, pp. 382 (2007).

9. Abdel-Shafy, H. I. and Mansour, M.S.M., Overview on water reuse in Egypt: Present and future. J. Sustainable Sanitation Practice, 14, 17-25 (2013).

10. Abdel-Shafy, H.I. and Aly, R.O., Water issue in Egypt: Resources, pollution and protection endeavors. Central European J. Occupational \& Environ. Medicine, 8 (1), 1-21 (2002).

11. Abdel-Shafy, H. I., Al-Sulaiman, A. M. and Mansour, M.S.M., Anaerobic / aerobic Treatment of greywater via UASB and MBR for unrestricted reuse. J. Water Science and Technology, 71 (4), 630-737 (2015).

12. Gabriel, M. K., and Williamson, D.G., Principal biogeochemical factors affecting the speciation and transport of mercury through the terrestrial environment. Environ. Geochem. Health, 26, 421 - 434 (2004).

13. Kalay, M. and Canli, M., Elimination of essential $(\mathrm{Cu}, \mathrm{Zn})$ and non-essential $(\mathrm{Cd}$, $\mathrm{Pb}$ ) metals from tissue of a freshwater fish Tillapia zill. Turkish. J. Zool. 44, $429-$ 436 (2000).

14. Larsson, A., Haux, C. and Sjöbeck, M., Fish physiology and metal pollution: results and experiences from laboratory and field studies. Ecotox. Environ. Safe, 9, $250-281(1985)$.

15. Nemesok, J.G. and Hughes, G.M., The effects of copper sulphate on some biochemical parameters of rainbow trout. Environ. Pollut. 49, 77 - 85 (1988). 
16. Rashed, M. N., Monitoring of environmental heavy metals in fish from Nasser Lake. Environ. Ind. 69, 27 - 33 (2001).

17. Adel, P.D. and Papoutsouglon, S.E., Lethal toxicity of cadmium to Cyprinus Carpio and Tlapia aurea. Bull. Environ. Contam. Toxicol, 37, 382 - 386 (1986).

18. Jagoe, C.H., Shaw-Allen, P. L. and Brundage, S., Gill, Na +, K+ -ATPase activity in Largemouth Bass (Micropterus salmoides) from three reservoirs with different levels of mercury contamination. Aquatic Toxicology, 36, 161 - 17 (1996).

19. El-Gamal I.M. and Abdel-Shafy, H.I., Role of micropollutants in the evaluation of wastewater in Egypt. J. Environmental Protection Engineering, 16(3-4), 5-13 (1990).

20. Guo, T., Delaune, R. D. and Patrickjr, W.H., The influence of sediment redox chemistry on chemically active forms of arsenic, cadmium, chromium, mercury and zinc in the estuarine sediment. Environ. Int. 23, 305 - 316 (1997).

21. Stohs, S.J. and Bagchi, D., Oxidative mechanisms in the toxicity of metal ions. Free Radical Biology and Medicine, 18 (2), 321 - 336 (1995).

22. Abdel-Shafy, H. I., Inka H. and Werner H., Upgrading of decentralized ponds for municipal wastewater treatment and restricted reuse. J. Water Reuse and Desalination, 01.3, 141-151 (2011).

23. CCME (Canadian Council of Ministers of the Environment), Canadian environmental quality guidelines, 1999, Canadian Council of Ministers of the Environment, Winnipeg, Canada, p. 126 (1999).

24. APHA. Standard Methods for Examination of Water and Wastewater Including Bottom Sediments and Sludges. Am. Pub. Health Ass., N.Y. $14^{\text {th }}$ ed., p.769 (2005).

25. Baldwin, D. H., Sandah, L. J. F., Labenia. J. S. and Scholz, N. L., Sublethal effects of copper on cono salmon: Impacts on non-overlapping receptor pathways in the peripheral olfactory nervous system. Environmental Toxicology and Chemistry, 22 (10), 226 - 2274 (2003).

26. Protasowicki, M., Bioaccumulation and distribution of heavy metals in fish organs. Proceedings $21^{\text {st }}$ EMBS (European Marine Biology Symposium) 43, 609 - 614 (1989).

27. Benson, N.V., Essien, J.P., Williams, A.B. and Bassey, D.E., Mercury accumulation in in fishes from tropical aquatic ecosystems in the Niger Delta. Nigeria. Current Science, 92 (6), 265 - 272 (2007).

28. Fowler, B.A., Carmichael, N.G., Squibb, K.S. and Engle, D.W., Factors affecting trace metals uptake and toxicity to estuarine organisms-cellular mechanisms In Vernberg, F.J. (Ed.) Biological Monitoring, of Marine Pollutants. Academic Press, New York-Toronto-London-Sydney. pp. 145 - 163 (1981).

29. Romeril, M. Q., The Uptake and Distribution of ${ }^{65} \mathrm{Zn}$ in Oysters Edited by Miller of Clarrson T.W. 68 - 95. Thomas. Spring field (1971).

Egypt. J. Chem. 58, No. 5 (2015) 
30. Helcom J. T., The Baltic marine environment 1999-2002. Baltic Sea Environment Proceedings, 87, 1 - 47 (2003).

31. Zarski, T. P., Zarska, H., Sokol, J. and Beseda, I., Mercury distribution in the reproductive organs and muscles of fish in differently contaminated waters. Ecológia (Bratislava), 14 (4), 443 - 448 (1997).

32. Yilmaz, A. B., Comparison of heavy metal levels of Grey Mullet (Mugil Cephalus) and sea Bream (Sparus aurata) caught in Iskenderun Bay (Turkey). Turk. J. Vet. Anim. Sci. 29, 257 - 262 (2005).

33. Hofer, R. and Lakner, R., Fischtoxikologie-theorie und praxis. Gustav Fischer. Stuttgart- New - York. pp. 1 - 164 (1995)

34. Wiener, J. G., Evolution of contaminant problem: Mercury in fresh water fish. Proceedings and Summary Report, USEPA/ 625/R- 02/005 (2002).

(Received 12/5/2015;

accepted $21 / 7 / 2015)$ 


$$
\begin{aligned}
& \text { التأثيـرالسمي لكلاً من الزئبتق والكادميـوم لى زريعـة } \\
& \text { - SparusAurata }
\end{aligned}
$$

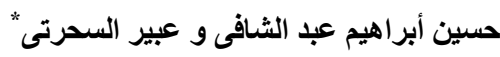

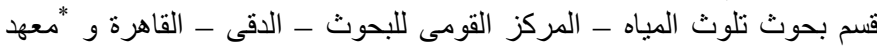

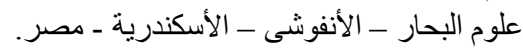

تم در اسة التأثير السمي لكلاً من الزئبق و الكادميوم على زريعة SparusAurata

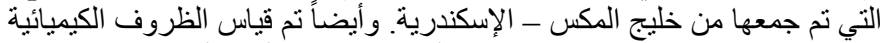

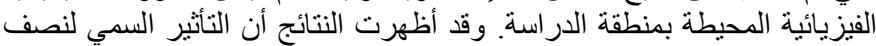
عدد الزريعة بعد 96 ساعة للزئيق و الكادميوم

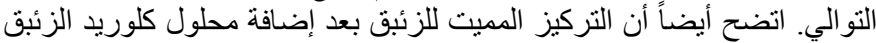
كان $\mathrm{HgCl}_{2}$

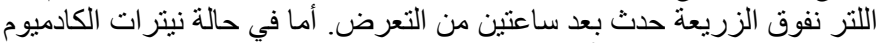
فبدأ النفوق عند تركيز إلى

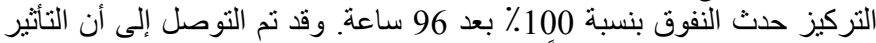

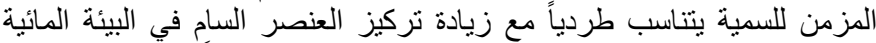

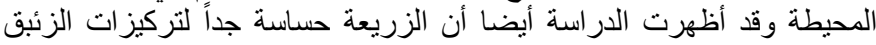
و الكادميوم. 
